\title{
The Trouble With Alexander Medvedkin: Ideological Errors in New Moscow (1938)
}

\author{
HANIN HANNOUCH \\ IMT Lucca, Institute for Advanced Studies.
}

This article studies the ideological errors in Alexander Medvedkin's film New Moscow, or what precisely lead the censors to ban the movie even before its release scheduled for early 1939. The movie tells the story of Aliosha, an engineer from a Soviet remote village, who goes to Moscow to display his creation: a moving miniature model of the capital, which ends up malfunctioning. My contention is that not only was the last segment of the film, in which this model goes haywire, a representation of the beautiful capital before the revolution instead of its modernized glory, but that Medvedkin has embedded several subversive elements in the film which could not have been edited out. Through the paradigm of socialist realist literature studied by Katerina Clark, Medvedkin's work is examined against this literary form with focus on four scenes: Aliosha's arrival to Moscow and his interrupted train ride, his first experience of the capital in the metro, his singing at the carnival and lastly the display of his askew model of Moscow.

\section{INTRODUCTION}

The rupture sought out by socialist realist aesthetics not only with "corrupt" western film forms but also with its own formalist antecedents lead to the reconsideration of comedy and the role of laughter in the construction of the socialist edifice. For formalist theorist Yuri Tynyanov (1894-1943), comedy and derision are intertwined: “The comic form (...) is by its very nature derivative, profoundly determined by the structure it ridicules." ${ }^{1}$ It can only mock the very situation that made its own existence possible and it can only be directed at the society in which it is created. But according to Vladimir Blium (1877-1941), this very society must not be ridiculed, because it is not an oppressive structure. Blium spoke against satire because satire is the weapon of the downtrodden masses against the system oppressing them, and since oppression befell nobody in the Soviet Union, satire

\footnotetext{
${ }^{1}$ Serguei Alex Oushakine, 'Laughter Under Socialism. Exposing The Ocular in Soviet Jocularity', Slavic Review, 70 (2011), 247-255 (рp.249).
} 
had no role to play. ${ }^{2}$ Soviet author and satirist, Mikhail Zoschchenko (1894-1958) claimed at the first congress of Soviet writers in 1934 that satire is necessary but it must be favourable; a statement which did not at all clarify the aims and intentions of satire. At the juncture of these theoretical debates, Soviet filmmaker Alexander Medvedkin (1900-1989) found himself in the line of fire and although his film Happiness (1934) was defended both by Anatoly Lunacharsky (1875-1933) and Sergei Eisenstein (1989-1948), his following work, New Moscow (1938), already regarded with suspicion, was withdrawn from circulation even before its premiere scheduled for January 1939. On a narrative level, the film recounts the journey of an engineer named Aliosha from his hometown 3000 miles away from Moscow to the capital in order to exhibit his ingenious living model of Moscow. In the last segment of the film, Aliosha's model malfunctions and projects images of the city not in its modernist glory, three years after the 'General Plan For the Reconstruction of Moscow', but in its pre-Soviet Union beauty, to a laughing crowd over a speech about the great achievements of Joseph Stalin.

According to Grigori Ryklin, ${ }^{3}$ the ideological reason for which the film was banned is that it displaced the image of the reconstruction of Moscow in its past, present and future. ${ }^{4}$ And indeed, upon the first viewing of the film, the last scene alone ridicules the immense modernization efforts of the city and generates laughter from the crowd, giving the censors enough ideologically-incorrect material to ban the film. However, my contention is that had this scene been the only subversive element in the entire film, it could have been edited out. ${ }^{5}$ But since the whole of the movie was banned and no attempts at salvaging it were undertaken, a closer inspection of the work is likely to reveal a second level of reading in which subversive elements threaten the political coherence of the work and betray the filmmaker's stance against socialist realist aesthetics. This research seeks to point out incisively what cannot be edited out of the film in order to render it ideologically correct, from the gaze of the censors. What the censors (and Stalin himself) found precisely objectionable about the film has not left any material traces; however, Katerina Clark's work on socialist realism as a literary and artistic paradigm is very pertinent for approaching Alexander Medvedkin's film, as it allows the viewer to compare the expected form of a work of art to the delivered final product of the director. The gap

\footnotetext{
${ }^{2}$ Emma Widdis, Alexander Medvedkin (New York: KINOfiles Filmmaker's Companion, 2005), p.13.

${ }^{3}$ Grigori Efimovich Ryklin (1894-1920) was the editor of Pravda. He criticized Medvedkin's film in "Pravda, $7^{\text {th }}$ of January 1939. No. 7."

${ }^{4}$ Urussowa, Janina, Das Neue Moscow. Die Stadt der Sonjets im Film 1917-1941 (Köln: Böhlau, 2004), p. 39.

${ }^{5}$ For example, in Sergei Eisenstein's film from 1928, October, Stalin's rival Leon Trotsky was edited out.
} 
between the two is too radical to be bridged because the entire film is precisely too determined by the structure it ridicules: it borrows its form but either substitutes its ideological content with a farcical one or suspends its power altogether.

The first part of my writing deals with these socialist realist characteristics and then sets out to analyse the first of four scenes from New Moscow. The first scene is Aliosha's journey to Moscow with emphasis on the role of Heinrich the pig read against these literary traits; the second is the metro ride of Aliosha and his friends read against the experience that Soviet citizens were supposed to have in the newly-finished underground; the third is the carnival segment reconsidered through the lens of Mikhail Bakhtin's work on carnivals and festive laughter; and the fourth and final one is the exhibition and malfunction of Aliosha's model in Moscow and his eventual return home.

\section{THE SOCIALIST REALIST LITERARY PARADIGM}

The destruction, collectivization and industrialization stemming from the first Five-Year plan (1928 to 1932), saw a change not only in the very fabric of Soviet society but also in the cultural paradigm that propelled the emergence of socialist realist literature as the only art form capable of expressing Stalin's idea of 'socialism in one country'. ${ }^{6}$ Architecture and literature met the same fate in 1932 with the liquidation of not only all literary and artistic organizations to pave the way for the state monopoly under the 'Union of Soviet Writers', but also the termination of all independent architecture societies, henceforth replaced by the Union of Soviet Architects (SSA). ${ }^{7}$ For both aesthetics and architecture, socialist realism was considered "the only acceptable method for artistic work" ${ }^{8}$ without any explanation as to what kind of work this method would entail, only that no foreign elements were no longer allowed. That same year, Stalin issued an authoritative statement of policy on literature that still lacked any clear definition of the aesthetics required or the work to be commissioned. By that time, "the foundation of socialist society has been laid,

\footnotetext{
${ }^{6}$ A theory of Joseph Stalin dating from 1924 that emphasizes the internal strengthening of Russia, the only country where the communist revolution did not fail.

7 Alexei Tarkhanov, Sergei Kavtaarade, Sergei, Stalinist Architecture (London: Laurence King Publishing, 1992), p.42.

${ }^{8}$ Birgit Beumers, A History of Russian Cinema (London: Bloomsbury Academic, 2009), p.78.
} 
now it was time to construct its edifice." "The establishment of this edifice was twofold: with the creation of a new aesthetic, came the rebuilding of the city and the guidelines that were finally given to socialist realist writers coincided with the renovation of Moscow. Works of literature, now under complete union control, were to have their legitimacy examined by party leaders and had to live up to the great Soviet project of the capital, whose main street was renamed in Maxim Gorki's honour. ${ }^{10}$ The characteristics of socialist realist literature were intimately linked with the newly constructed and centralized Soviet Union with Moscow as its red star. Katerina Clark focuses on four attributes in socialist realist literature, which, one by one, were corrupted by Medvedkin in New Moscow; and this corruption intimately extends itself to the representation of the city and its power of attraction:

1. The positive hero is usually the main character endowed with all possible virtues. "His career must encapsulate the country's evolution towards communism". ${ }^{11} \mathrm{He}$ is the crux of ideology, while simultaneously representing its subject and object. As a subject, the Party legitimizes itself only through the existence of its people, as a manifestation of the people's will and as an embodiment of their desire, all of which culminate in the hero. It is the activity of the positive hero that makes the Party what it is and validates it. The hero is also the object of ideology, in the sense that the projects undertaken by the Party are staged for his gaze: The city is reconstructed as an ideal for him to live up to, the metro is re-made because only the most expensive material are worthy of him and it is this staging that he has pay attention to, accept and enjoy. His enjoyment proves that the Soviet society is on the right track, and it affirms its work.

2. Rapport of the periphery with the centre: This opposition is important for the progression of the hero from the periphery to the centre, especially when read in light of the centralization of Soviet Union with the 1936 constitution. A progression from the outside of Moscow to the insides of the capital, which is the holy of the hollies, is essential for the hero to "mediate between Moscow and the

\footnotetext{
${ }^{9}$ Katerina Clark, 'Socialist Realism and the Sacralizing of Space', in The Landscape of Stalinism, The Art and Ideology of Soviet Space, ed. by Evgeny Dobrenko (Washington: University of Washington Press, 2003), pp. 3-18 (p.4).

${ }^{10}$ Katerina Clark, Moscow, The Fourth Rome. Stalinism, Cosmopolitanism, and the Evolution of Soviet Cultural, 1931-1941 (Massachusetts: Harvard University Press, 2011), p.80.

${ }_{11}$ Clark, Socialist Realism, p.10.
} 
periphery", ${ }^{12}$ the sacred and the profane, the modern and the backward. Yet reaching Moscow is impossible as it is a place only for heroes and leaders. The greatness of its space is reserved for the greatness of its people. "The role of the masses is to be forever in motion, striving to attain "Moscow" [...] But they can attain Moscow only figuratively, fleetingly or tokenly."13

3. The journey leading to this mediation must go unrepresented. The hero should not experience the 'in-between', as in the place that is on the outside of the periphery but is still not quite the capital. This realm is the leftover of centralization - it cannot be seen nor be inscribed in a continuity of space because there is no continuity between the old and the new and most importantly, there are no residues. The old is the periphery, the new is Moscow, in between is nothingness. "It is important to represent the "new" as a complete transformation of the old." 14

4. The role that Stalin plays, should the hero meet him or any other authoritative figure representing him, is that of a "tribal initiation, a kind of sexual initiation". ${ }^{15}$ Stalin stands on the outside of the realm of Man, he is devoid of sexual desire and love interests, he mediates between the two lovers in the film and presides over their future happiness without being part of it.

\section{THE START OF THE SUBVERSION: ALIOSHA HEADS TO MOSCOW}

Read in light of these attributes, New Moscow does narrate Aliosha's journey from the periphery to the centre but clearly distinguishes itself from these aesthetic-ideological requirements: as a seemingly positive hero, Aliosha is a young, smart and motivated Soviet citizen living in the periphery, some 3000 miles away from Moscow during the era of modernization of the Soviet Union. He has created a moving model of the capital that functions as a catalyst to his journey to the centre in order to exhibit it, thus proving (initially) that the attraction exercised by Moscow draws citizens from all quarters of the

\footnotetext{
12 Clark, Socialist Realism, p.10.

${ }^{13}$ Clark, Socialist Realism, p.14.

${ }^{14}$ Clark, Socialist Realism, p.10.

${ }^{15}$ Clark, Socialist Realism, p.16.
} 
country closer to it: "The Periphery defines itself according to recognition from the centre" $^{\prime 16}$ and Aliosha sets out to gain this recognition for his work from the holly of hollies. The subversion of the socialist realist literary model starts five minutes into the film, the moment when Aliosha's train ride from the periphery to Moscow, which is supposed to go unseen, is actually represented. Not only is there no clear rupture between the past (the periphery) and the present (post-General Plan Moscow) as customary, but the mandatory invisible progression to the capital is decomposed into a space completely independent of the centre and detached from the periphery, where one farce after the other are juxtaposed to the serious context of this very progression. Had the film been in accordance with the socialist realist guidelines, then the train ride would have not been filmed to begin with, yet while on board, Aliosha sings and plays on the accordion the leitmotiv of the film for the first time: a song about the beauty and fame of the capital. This patriotic chant is followed by a farce at an unidentified train stop on the way to Moscow, where Olia, a student at Timiryazev academy ${ }^{17}$ who is also on her way to defend her thesis about a new breed of pigs loses Heinrich, her pig and best specimen. She asks for Aliosha's help and they both chase the animal into prairies and tunnels in a setting reminiscent of slapstick comedy films with the sound of the beast erupting loudly several times mixed with the non-diegetic music in the background.

If cinema was meant to participate in the socialist ideological project and "is supposed to assist in the creation of a new Soviet alphabet" ${ }^{18}$ by making the modernization of Moscow more intelligible, then Heinrich the pig is a confounding element: He is either lost on its way to Moscow, lost in Moscow, or mistaken for another pig altogether. The antagonistic juxtaposition of on one hand, Heinrich, comic farces and fun and on the other hand; Moscow, order and seriousness is repeated throughout the film and systematically undermines the solemnity and grandness of the Soviet modernization. After the train leaves without Aliosha and Olia, the model that Aliosha created of the city is made visible and referred to by Babushka (his grandmother) as "unmiraculous". She says to Zoia: "There are no miracles, dear lady! This is electrical engineering, chemistry, mechanics and physics", and it is with the help of science that she and Aliosha will display the live model of Moscow. As soon as this premise is established,

\footnotetext{
${ }^{16}$ Emma Widdis, Visions of a New Land. Soviet Film From The Revolution to The Second World War (New Haven: Yale University Press, 2003), p.176.

${ }^{17}$ Referred to today as the 'Russian State Agricultural University'.

18 Oksana Bulgakowa, 'Spatial Figures in Soviet Cinema of the 1930s', in The Landscape of Stalinism, The Art and Ideology of Soviet Space, ed. by Evgeny Dobrenko (Washington: University of Washington Press, 2003), pp.51-96 (p.62).
} 
about Aliosha's work in Moscow, the pig emerges once more, still lost in the prairie and later gets mistaken with another pig at a farm. Olia and Aliosha hold the 'real' Heinrich next to the 'fake' Heinrich together for comparison but are left bewildered. This comparison between the real and the fake echoes not only the difference between the 'fake' model of Moscow and the city itself but also the difference between Moscow and other cities: "Moscow, however, was not merely a model - it was also the seat of power. Consequently, it came to function as an extraordinarily privileged space. All other cities were limited merely to approaching it." ${ }^{\text {"19 }}$

The difference between Aliosha's model and the city itself would soon be abolished because, same as the model will become alive, the city would as well as buildings were literally moved to widen the streets. Once Heinrich is found, Aliosha and Olia realize that they have missed their train. They are both late for Moscow (the most sacred Soviet space) because they were chasing a pig. The antagonistic setting of Heinrich either before or after a serious event is also present towards the end of the film: Heinrich is lost and found again between Olia's thesis defence in Moscow and the exhibition of Aliosha's model, also in Moscow. The painter Feida visits Olia to proclaim his love, this time in a likewise serious context - right before the arrival of the professors to assess her work on the pig pedigree - but since the Heinrich is lost, the succession of farces resumes as Feida brings a "fake" Heinrich to soothe the distraught student. After they chase the real beast and finally manage to find it, a shot of a crowd rushing to see Aliosha's work emerges. The serious act of her thesis defence is hinted at but visually omitted. What the viewer retains with respect to Olia is her contribution to the farces and not her solemn student work. Editing out Heinrich and the succession of farces would have already implied the omission of around fifteen minutes of the film. Therefore, while borrowing socialist realism as a literary genre and the form of a progression from the periphery to the centre, Medvedkin integrates subversion deep in the seemingly politically correct journey in order to undermine the power of the attraction of Moscow and to represent this journey as humorous. However, the position of farces in regards to the representation of the city is not the only fashion in which the image of Moscow is weakened - the arrival of Aliosha, Olia, Zoia (Aliosha's love interest) and Heinrich to the capital and their first metro ride together represents yet another subversive of gesture.

${ }^{19}$ Clark, Socialist Realism, p.6. 


\section{The UnCONSUMED MYTHOLOGY OF THE METRO: Aliosha IN Moscow}

"Citizens absorbed the values and ethos of Stalinist civilization as they rode the metro and as they consumed its mythology."20

Situated after the enquiries of the painter Feida and Babushka about the modernization of Moscow, the metro scene brings Aliosha, his friends and Heinrich right into the heart of the city. ${ }^{21}$ This scene starts with a shot of several lamps that illuminate the ceiling at a busy unidentified metro station with walls of marble as the group decides that the only way for Olia to deliver the animal on time is to disguise him as a baby and sneak him into the metro. They quietly ascend the electric stairs with Heinrich wrapped as an infant and whose sound erupts when they are seated in the train. A paediatrician with bad eyesight, who is seated next to them, examines him while the group pretends that Heinrich has mumps. He agrees that infant is indeed ill but has "a charming face" despite his protruding pig nose. Aliosha, Olia and Zoia exit at the next metro station and leave. What is ideologically incorrect about this simple metro ride and the disguising of the pig as a baby? The confrontation between the film characters' experience of the metro and the discourse about what Soviet citizens ought to experience in the great underground Soviet project sheds light on the gap between the ideological imperative of enjoyment and the underwhelming representation of this very enjoyment.

Since the Bolshevik revolution, peasant culture was considered self-contained, socially indistinct, and able to strongly resist changes from the outside. Rural Russia was the enemy and the Bolsheviks and Stalin were prepared to modernize it through ideology, industrialization and socialist realist aesthetics. ${ }^{22}$ Stalin likewise substituted the character of the struggling peasant in the avant-garde's early films with the image of heroic leaders that only refer back to him. With the Great Purges (1937-1939), came the great beauty and the purification of space, it was "a final act of purifying and perfecting the new society, and

\footnotetext{
${ }^{20}$ Andrew L. Jenks, 'A Metro on the Mount. The Underground as a Church of Soviet Civilization', Technology and Culture, 14 (2000), 697-724 (p.699).

${ }^{21}$ After her arrival to Moscow, Babushka takes a cab and looks at the trams of the capital through the window. The shot that follows shows the painter Feida, who is trying to draw an urban landscape of the city, only to realize that the city is disappearing and buildings are being demolished. He says, "one day I paint it, the other day it's nowhere to be found. Either they demolish it all, or built something new." Since the scenery he wanted to paint disappeared, Feida calls a bureaucrat and blames him for it while Babushka calls to ask about the exhibition Aliosha wants to participate in. Aliosha then arrives with his friends in the capital.

22 Abbot Gleason, 'Ideological Structures', The Cambridge Companion to Modern Russian Culture, ed. by Nicholas Rzhevsky (Cambridge: Cambridge University Press,1998), pp. 103-125 (p.117).
} 
hence making it more beautiful." 23 The metro scene takes place during the Purges, at a time when Stalin lamented the cultural revolution's fixation on technology and practical affairs that eclipse ideology and beauty. ${ }^{24}$ The beauty of the city was supposed to engender love for the city ${ }^{25}$ especially for the peasants who immigrated to newly industrialized areas yet were still considered backward. The correct representation of the metro scene would be a long display of the beauty of the underground project, a discussion about the hard work it entailed and amazement at this achievement; but Olia who studies agriculture, Aliosha who is from the rural periphery, and even city-girl Zoia, do not stop to marvel at the edifice of Stalin. They are neither interested nor amazed they merely use the metro for practical purposes, ignoring its ideology and beauty. The camera conveys perfectly their neutrality by under-representing the metro. It is visually mentioned but no heed is taken of it. The residents of Moscow were urged to raise their heads at Mayakovski station and they would see the sky because the underground is so heavily lit, but the film viewer barely has a quick glance at the lamps in the ceiling. ${ }^{26}$ No close-ups can be found of the precious materials used in the architecture, decorative artworks were not emphasized and the different themes of historical architecture that are present in the metro were not displayed, all of which are important elements of Stalinist architecture that the leader (allegedly) chose himself for his people. ${ }^{27}$ Stalin's choice of symbols in the metro, laden with political messages of the conquest of nature and the destruction of capitalism played absolutely no role in the movie. The world's 'best metro', the living symbol that socialism and Soviet engineers vanquished nature was reduced to its very basic function, that of transporting the characters of the film to their needed destination without any astonishment as to its efficiency, speed and beauty. ${ }^{28}$ Frescoes, granite columns, crystals and marble facings in the underground project were reduced to a total of 11 shots constituting the entire metro scene, which is just shy of being three minutes long. What the viewer actually sees of the metro in Moscow are the granite walls in the background when the characters are talking to one another, the lamps in the ceiling before they ascend on the escalators and the fancy columns on the train platform when they exit the train. The magnitude of Stalin's project, the work in which he tremendously

\footnotetext{
23Jenks, p.711.

${ }^{24}$ Clark, Moscow, p. 108.

${ }^{25}$ Werner Huber, Hauptstadt Moscow. Ein Reiseführer durch Das Baugeschehen der russischen Metropole von Stalin über Chruschtschow und Breschnew bis heute. (Zürich: Helmut Spieker, 1998), p.47.

${ }^{26}$ Jenks, p.697.

27'Kunst und Macht im Europa der Diktatoren 1930 bis 1945', exhibition catalog, (London: Hayward Gallery, 1995-1996) p.191.

${ }^{28}$ Jenks, p. 704.
} 
invested himself, the very execution of his socialist realist aesthetics that is meant to be simple and readable to everyone, especially for the peasants, went unread. ${ }^{29}$

This is the case of a letter (an ideological message) that arrived at its destination (communicating with the peasants) but was left unopened (the message was neither deciphered nor interpreted). The mythology carefully orchestrated around the metro is left unconsumed. The goal of the metro project - that of offering citizens a dose of socialist realist beauty so as to stimulate their love for the Soviet Union and their admiration of their leader - was compromised. Aliosha, Heinrich, Zoia and Olia were unimpressed by the metro's splendour and they did not marvel at Stalin's genius through their experience of his architectural work. After the underwhelming metro scene, the film moves to a carnival setting in a twelve-minute long segment titled "Tonight is a Carnival Night!" in which the power of authorities is not undermined but suspended.

\section{V. 'TONight is a CARnival Night!': AUTHORITY IS SUSPENDED}

The ideological error in the twelve-minute long segment "Tonight is a Carnival Night" in New Moscow can be understood through the thesis of Mikhail Bakhtin (1895-1975) ${ }^{30}$ on the carnival and the grotesque in the works of the French author and humanist François Rabelais (1494-1533) titled Rabelais and His World, as well as through the choice of the bear as disguise. Although we cannot prove that Medvedkin and Bakhtin knew one another, Bakhtin's theory is most useful to our determination of the subversive quality of the film. Bakhtin's thesis focussed on the carnival and the theme of festive laughter - both of which originate from peasant culture. In Medvedkin's film, Aliosha and Babushka leave their remote village and go to Moscow, thus introducing this very element of peasantry in the city. The carnival in Bakhtin's work was thought of as a place of relief for the repressed masses where the crossing of boundaries, the mocking of authority, and where rebellious views were allowed. Several oppositions coexisted in such a world: official and the unofficial, ridicule and celebration, crowning and the dethroning, elevation and debasement. ${ }^{31}$ At a carnival, existing social rules are temporarily suspended and folk humour forges its own reality outside of this official realm and parodies social regulations.

\footnotetext{
${ }^{29}$ Clark, Moscow, p. 112.

${ }^{30}$ In 1929, Bakhtin was arrested and on account of very poor health, was exiled for 6 years to Kustanai in Soviet Central Asia. Despite his prolific writings, Bakhtin's work was only rediscovered in the 60s. ${ }^{31}$ Pam Moris, The Bakhtin Reader. Selected Writings of Bakhtin, Medvedev, Voloshinov (London: Bloomsbury Academic, 1994), p.20-21.
} 
The laughter generated by this parody is the laughter of all people. "Festive laughter is not an individual reaction to an event. It is the laughter of all people. It has a universal scope, directed at everyone, including the participants. It is also ambivalent, triumphant and happy yet mocking and derisive." 32 New Moscow visually suspends the ideas of socialist realism propagated in the Soviet Union in the 1930s as well as the cult of Stalin as the ultimate leader. The sequence "Tonight is a Carnival Night" is subversive in three fashion:

1. First, the title of the sequences appears and then the director cuts to a series of three shots that simultaneously highlight but suspend the dominion of Soviet authorities, which would have most likely been problematic to censors. The first shot takes place on the outside where people in festive disguises move very slowly. Above them, two silhouettes of Lenin and Stalin in profile occupy two thirds of the composition. The second shot takes place on the inside where people move slightly faster than they do in the first scene. We notice two of them in the foreground disguised as animals; one as a giraffe and one as a horse. In the background is an oversized poster of a statuesque hero with a ship and several canons dominating the two thirds of the image. The last shot of the series takes place once again on the outside, where people are now moving much faster and running around in circles. Ten symbols of the Party are elevated on poles and suspended high in the sky occupying two thirds of the shot. The visual representation of this parallel alternative world undermines the Soviet project. The State is not the only controller of subjectivity, and the suspension of its rule along with the representation of this suspension, albeit momentarily, threatens the State in real life. These three opening shots, with the symbols of the Soviet Union occupying most of the image, recognize the power of Stalin but simultaneously create some distance from it. While the images are fixed in the horizons, the population opposes itself to it and moves rapidly. This movement culminates in Aliosha's performance. Since the participants at the carnival are dancing animals, their own everyday subjectivity is suspended, which in turn, suspends ideology. The image of the hardworking, serious and dedicated worker serves as the crux of ideology, it is the basis of the Party's rule and legitimizes the regime. Therefore, by having the average person look as undignified as in the film, this representation refers to what is undignified about the system. The carnival coexists with the

\footnotetext{
${ }^{32}$ Moris, p.200.
} 
social order as an alternative to it, it recognizes the authority of leaders but temporarily takes no notice of it, allowing every character to change and develop: Babushka's participation at the carnival transforms her, if only momentarily, from the grandmother chasing her grandson in the big city to a woman who rests, conceals her real age thanks to the mask, gets seduced by a younger guy and eventually dances with another man. Zoia, who remains undisguised, refuses to answer Feida's marriage proposal regardless of his numerous enquiries. He does not realize that the rules of communication of the outside world have been paused for the duration of the event.

2. Secondly, Aliosha problematically juxtaposes incompatible contexts: At the beginning of the carnival, he is represented as a polar bear dancing happily with an accordion hanging from his outfit. He then removes his animal head and is crowned a party hat and, in this comic attire, happily sings the (serious) leitmotif of the film surrounded by balloons. The crowd cheers him on when he finishes the song. Once again the ridiculous (his appearance) is juxtaposed with the serious (the patriotic content of the song). Aliosha's performance of the film's leitmotif marks a point of fusion between the irreconcilable opposites that characterize the carnival and brings the sacred ideology right into the profane festival.

3. Thirdly, the choice of the bear as Aliosha and Feida's disguise is also an ideological error. It stems from the long tradition of the usage of the bear as a symbol of Russia, which has been thoroughly examined by Anne Platoff. Firstly, the director's own name, 'medved' means 'bear' or 'honey eater.' ${ }^{33}$ In Russian folklore, the bear is considered the ancestor of early eastern Slavs and has developed special bond with them. Moreover, it has a "supernatural relationship with humans, either a man or a woman, who has become the consort of a bear, or feature the offspring produced by a human-bear coupling." ${ }^{34}$ The love triangle between Zoia, Feida and Aliosha can be read as a satirical re-interpretation of this fairy-tale since the men are merely disguised as animals trying to consort with the woman. Likewise, the bear is often used in Russian heraldry, in reference to a preSoviet tradition, especially in northern territories. For example, the seal of the

\footnotetext{
${ }^{33}$ Anne M. Platoff, "The "Forward Russia" Flag. Examining the Changing Use of the Bear as a Symbol of Russia', Raven: A Journal of Vexillology, (2012). 99-126, p.100.

${ }^{34}$ Platoff, p.101.
} 
Chukotka Autonomous $\mathrm{Okrug}^{35}$ features a polar bear and that of Yamalo-Nenets Autonomous $\mathrm{Okrug}^{36}$ features two bears ${ }^{37}$. This association between bears and the North is established since Aliosha, who disguises himself as a bear, is from the northern part of Siberia. After the Russian revolution, the image of the bear started to represent the entire Soviet Union, thus making any comic use of the symbol susceptible to State disapproval. ${ }^{38}$ The bear as symbol, which by that time represented the entire Soviet Union, is represented as either desperate for love in case of Feida, or ecstatic and ridiculous in case of Aliosha. The animal does refer to the director's last name, but as a consistent element in historical and visual culture of the Soviet Union, it is displayed in a festive, ridiculous and undignified situation: accompanying an old woman, dancing a folk dance, stuck in a love triangle and then singing merrily about the beauty of the capital. It is no longer part of national heraldry elevated on flags and official seals.

As well as this, depicting people as animals rejects the Enlightenment notion that animals are innocent creatures endowed with souls and degrades the human being who has transformed himself into an animal. And since ideology rests on its dignified and honourable citizen, undermining the person and transforming him into an animal, subverts ideology. "[Animals] are creatures positioned lower than humans, intellectually and morally inferior to us. If this premise is accepted, then depicting a human as an animal is indeed a disparaging critical gesture. By drawing a comparison between people and animals, the satirist suggests that humans are no wiser than animals and no more worthy of respect." 39

\section{Aliosha's MODEL: Moscow AS A TIME MACHINE}

"A fundamental idea of the socialist realist system: An emphasis on the greatness of space as a guarantee of the greatness of time - in other words, of the historical record." 40

\footnotetext{
${ }^{35}$ Chukotka Autonomous Okrug is a federal subject of Russia, located in the Russian Far East. ${ }^{36}$ Yamalo-Nenets Autonomous Okrug is a federal subject of Russia, located in the north of Russia. ${ }^{37}$ Platoff, p.102. ${ }^{38}$ Platoff, p.113.

${ }^{39}$ Karen L. Ryan, Stalin in Russian Satire, $1917-1991$ (London: University of Wisconsin Press, 2009), p.49.

${ }^{40}$ Clark, Socialist Realism, p.9.
} 
The last segment in New Moscow takes place right after Heinrich the pig is lost and found once more. It starts with the opening title of "today is the opening of the live model of Moscow" as a banner in the public space promotes. A succession of shots of moving cars highlights the chaotic movement of the heavily populated city that is about to be transposed upon this model. Aliosha tries to make his way through the crowd towards the centre the exhibition centre but arrives too late. The control of the model has been given to the painter Feida, who attempts to initiate the process, but an error occurs and the images of the city of Moscow go back in time by means of visual dissolve.

My contention for this scene is that the subversion is twofold: Firstly, the initial display of the malfunctioning model works as a time machine regressing to the city's prerevolutionary past, thus undermining serious discourse about the city that follows it. Secondly, the dialogue between Zoia and Aliosha after the exhibition likewise discredits Moscow's influence on Soviet citizens. The general plan of the reconstruction of the city of Moscow provides a subtext for the two contentions of this segment. After socialist realism was established as the official aesthetic of the Soviet Union under Stalin, it was now time to inscribe its capital in this artistic discourse and to distinguish it from all the other cities in the world. ${ }^{41}$ The entire space of Moscow is to be laden with the right symbols, which must always refer back to socialist realism, thus creating one and one only politically correct meta-text functioning as the guarantor of time. ${ }^{42}$ The General Plan was based on an initial urban plan titled "New Moscow" created between 1919 and 1923 by Ivan Scholtovski (1867-1959) and Alexei Schtschussev (1873-1949), which was concerned with the rapport of the periphery to the centre and remained truthful to the layout of the city and preserved historical monuments, including the church of Christ the Saviour. ${ }^{43}$ However, during the modernization efforts, no agreement was reached about the fashion in which the city was to be rebuilt. Finally, in June 1935 a decision was reached: Stalin must handle the general plan himself and a joint resolution of the Council of People's Commissars and the Central Committee on the General Plan for the Reconstruction of Moscow was published, signed by Stalin and Molotov and set out to construct the Palace of the Soviets on the site of the church of Christ the Saviour. ${ }^{44}$ When the reorganization of the city was underway, the media coverage was immense, which lead to very-well

\footnotetext{
41'Kunst und Macht im Europa der Diktatoren 1930 bis 1945', exhibition catalog, (London: Hayward Gallery, 1995-1996) p.189.

${ }^{42}$ Huber, p. 47.

${ }^{43}$ Tarkhanov, p.80.

${ }^{44}$ Tarkhanov, p.84.
} 
documented and weekly accounts all over newspapers and radios of the evolution of the construction sites. ${ }^{45}$ In the film, this reconstruction is visually rendered as a time machine, allowing the viewer, both the viewer of the film and the viewer in the exhibition room in the film, to take a look at Moscow in its pre-Soviet beauty, which appears by means of visual dissolve.

The Moscow seen before the exhibition of the model started was filled with people, chaotic and fast-paced whereas the one in the model is empty, but the Stranstnoi monastery and the Cathedral of Christ the Saviour look beautiful. However this aesthetic recognition of the pre-Soviet Union era is not in line with the socialist realist tendency of creating a brand new style, radically and symbolically divorced from its past. The greatness of space, which should guarantee the greatness of time, has to refer to the right space: that of socialist realism. Any other architectural reference to a bygone era threatens this process of integration of the city into the network of meaning of socialist realism and subsequently menaces its past, as in its historical records, and its future, as in the future of the Soviet Union. Likewise, the choice of the dissolve as a cinematic technique to render the transformation of Moscow from new to old and back to new again is particularly revealing. A jump cut would have simply represented the old state and then the new state of the monument through a clear rupture, but the dissolve confers a magical aspect upon this modification. The images the viewers see of contemporary Moscow literally dissolve and fade into the past; there is no rupture as dictated by the literary paradigm of socialist realism, only transformation in the form of rewinding to a bygone era. When Aliosha arrives and fixes the model, the images of the new Moscow emerge out of the old ones, presented over the speech uttered by Zoia about Stalin's project of the remaking of the city; he is the ultimate architect and he does not need the profane hand of another. ${ }^{46}$ Same as with Heinrich being positioned right before or after a serious discourse about the capital, the juxtaposition of the farce of the malfunctioning model before the "official" speech by Zoia, positions antagonistic elements after one another: the ridiculous precedes the serious. The enumeration of the achievements of the Bolsheviks cannot be seriously considered when accompanied by such a ridiculous representation of the general plan of Moscow. In showing the beauty of the old landmarks through the time machine, the future beauty of the capital, as promised by Stalin, is threatened and the whole project is undermined. Not only does the power of socialist realism to literally move buildings look

\footnotetext{
${ }^{45}$ Karl Schlögel, Terror und Traum. Moskau 1937 (München: Hanser, Carl GmbH, 2008), p.62.

${ }^{46}$ Urussowa, p.70.
} 
funny, but the costly materials used throughout the city are parodied and devaluated: "Palaces are hollowed out constructions, the precious materials of Stalinist architecture are completely profaned in the cinema. Marble, stone etc. are cardboard cards." ${ }^{47}$ The greatness of space - promised by socialist realism and meant to guarantee the greatness of present and future time - failed because the city reverted back to its past and this past was beautiful. The symbolic field of Moscow is conquered by the very monuments that it set out to destroy. Its present and future are at risk of being re-defined by the emergence of the past.

The second subversion occurs after the exhibition of the model in Moscow is over, when both Aliosha and Zoia decide to leave the capital, thus inverting the logic of centralization and the progression from the periphery to the centre (and not from the centre to the periphery) and contradicting the socialist realist paradigm of the journey of the positive hero. Aliosha and Zoia start by discussing if they should live in the capital or in 'the swamps' (as in the periphery, Aliosha's hometown). Zoia promises her beloved one a lot of good food and a brand new radio, but Aliosha discovers a letter from his friend back home who has, by now, completely shaved his beard. He has been 'modernized' and has decided to send Aliosha a blond lock of his shaved beard and a new photo of his face. That moment, in a counter-modern gesture, a sad Aliosha realizes the necessity of returning to his swamp and immediately departs. Although he has completed the socialist realist journey from periphery to centre, he has likewise inverted it by returning to the periphery instead of enjoying a prosperous life in Moscow. At the train station, a sad Zoia runs into Babushka who was also on her way back home. The latter suggests that Zoia should get on a plane if she wants to catch Aliosha in time in his native city knowing that she wants to be with him. Zoia gets on a plane and while airborne, she looks down and sees houses and trees thus contradicting the imperative of non-representation of inbetween spaces between the centre and the periphery. She even bought rain boots from Moscow to take with her to the swamps, thus shunning the power of the attraction of the capital. She has left the holy of the hollies to live in the swamps. After having subverted these literary paradigms, the only point where they are reinstated is at the end where her reunion with Aliosha takes place with a portrait of Stalin in the background. The attraction of the capital of the Soviet Union is not strong enough to separate her from her peripheral lover. Neither she nor him was transformed by Moscow.

\footnotetext{
${ }^{47}$ Bulgakowa, p.68.
} 


\section{CONCLUSION}

Knowing that New Moscow was at the epicentre of several debates about satire and the role of comedy, the fact that these theoretical questions were left unanswered created a divide between artists and censors through which the film and the director fell into the disfavour of the authorities. The lack of formal interdiction of representation meant that filmmakers were, in theory, somewhat left to their own devices in their artistic practice with no available text to fall back on à la Hays code. What should not be represented was never explicitly articulated and perhaps Alexander Medvedkin mistook the lack of guidelines for creative and critical freedom, carefully crafting his film with two possible interpretations: a love-comedy story, as well as an anti-modernisation film. What the censors most likely objected to in the film was not merely its last scene. If anything, the latter can be considered as the culmination of Medvedkin's refusal of the modernization of the Soviet Union and the big hype about Moscow. This culmination begins gently with the shaving of one's beard in the periphery, leading to the farcical train ride to Moscow but with the interruption of Aliosha's journey to the capital, escalating into his arrival and his underwhelming and hasty experience of the famous metro, followed by his festive suspension of regulations at the carnival, and finally exploding into his refusal of the changes done to the city, exemplified by the malfunctioning model that reverts back into time. Therefore, Ryklin's critique of the film that it downgrades the image of the reconstruction of Moscow and therefore the power of Moscow, does not pertain solely to the last segment, but to the entire carefully orchestrated construction of farces and the antagonistic juxtaposition of the serious and the ridiculous; none of which can be edited out while salvaging the film. The 'adherence' to the literary paradigm of socialist realism offers Medvedkin nothing more than a backdrop to his intimate deconstruction of this very paradigm: that of the life-changing journey to Moscow, which is transformed into a hilarious carnivalesque ride and an eventual trip back home to the swamps. This representation is cautious enough to go beyond the power of montage in the correction of politically deviant works, thus leading to the ultimate ban on the film. New Moscow can likewise be understood as a radical answer to the highly publicized cleansing of Moscow of its pre-revolutionary landmarks, best exemplified the demolition of its religious monuments such as the Church of Christ the Saviour. Perhaps to Medvedkin, the endless debates about the capital's urban planning, the commissioning of monumental projects such as the Palace of the Soviets, and the rapid pace of industrialization also provoke 
38 Hannouch - The Trouble With AleXander Medvedkin: IdeOlogical ERRORS IN NEW MOSCOW (1938)

another question: Why not just leave the city as it was?

This work is licensed under the Creative Commons Attribution-NonCommercial-NoDerivatives 4.0 International License. This allows others to download the author's works and share them with others as long as they credit the author, but they cannot change them in any way or use them commercially. To view a copy of this license, visit http:/ / creativecommons.org/licenses/by-nc-nd/4.0/. 